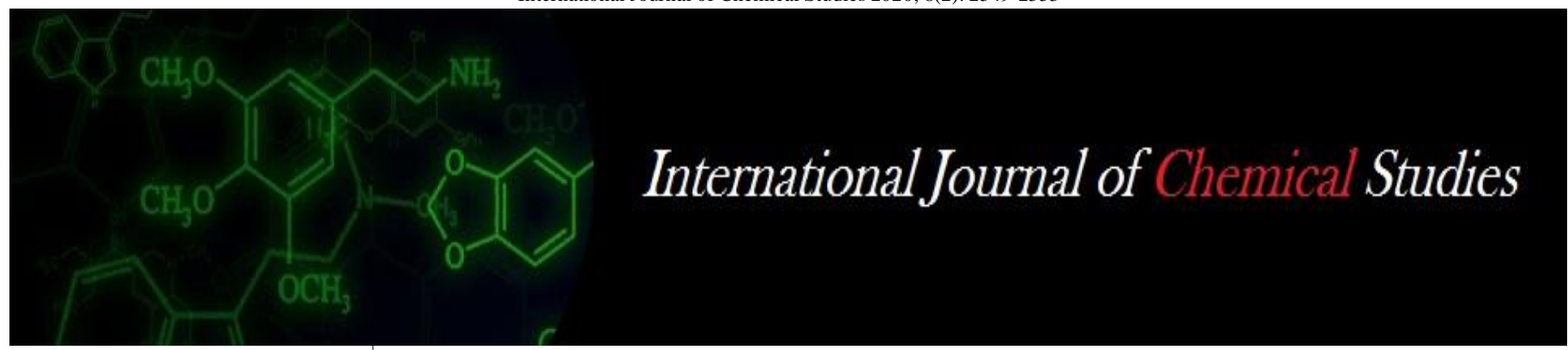

P-ISSN: 2349-8528

E-ISSN: 2321-4902

www.chemijournal.com

IJCS 2020; 8(2): 2549-2553

(C) 2020 IJCS

Received: 06-01-2020

Accepted: 08-02-2020

Desetty JMSNK Sri Veda

Department of Seed Science and

Technology, Bidhan Chandra

KrishiViswavidyalaya,

Mohanpur, Nadia, West Bengal, India

Prabir Chakraborti

Department of Seed Science and Technology, Bidhan Chandra KrishiViswavidyalaya,

Mohanpur, Nadia, West Bengal, India

Corresponding Author: Prabir Chakraborti

Department of Seed Science and

Technology, Bidhan Chandra

Krishi Viswavidyalaya,

Mohanpur, Nadia, West Bengal,

India

\section{Application of priming through organic compounds in oat (Avena sativa $L$.) seed production}

\section{Desetty JMSNK Sri Veda and Prabir Chakraborti}

DOI: https://doi.org/10.22271/chemi.2020.v8.i2am.9131

\begin{abstract}
To acquire potentiality under productivity and seed quality in Oat crop, the seed priming was applied through implication of three organic compounds viz. Naphthalene acetic acid (NAA), Salicylic acid (SA) and Nicotinic acid (NA) under diverse concentrations and treatment durations. In assessment, the observations allied to seven yield attributes for getting the real exposure of qualitative and quantitative plant nature. The treatments, T8 (NAA,75ppm) followed by T9 (NAA,100ppm) and T4 (SA,10ppm) were most operative with significant disparity among varied treatments except in seeds spikelet ${ }^{-1}$. The treatment durations showed non-significant demarcation though, $\mathrm{D}_{2}$ was hopeful for few characters predominantly in spikelet panicle ${ }^{-1}$, seed volume. Similarly, the interaction of treatment and duration showed non-significant demarcation in which $\mathrm{T}_{8 \mathrm{D}}$ interacted value was the top. Correlation values indicated positive effect for most characters especially in seed yield though exception was observed in few cases. Diverse treatments specified the extent of effects on seed or plant to upgrade the qualitative and quantitative manner. The treatments, $\mathrm{T} 8$ and $\mathrm{T} 4$ with precise duration may be added for fodder seed production to obtain capable seed.
\end{abstract}

Keywords: Seed priming, quality seed, organic compounds, oat

\section{Introduction}

Oat (Avena sativa L.) is an important annual crop under Poaceae family which obtained selfpollinated hexaploid nature $(2 \mathrm{n}=6 \mathrm{x}=42)$. Avena sativa $\mathrm{L}$. or white oat demonstrated the high energy reflection in its hull-free grain to facilitate the noticed progression on the crop considering its various utilisation as cereal food, feed, green or conserved fodder. It is a good source of protein, vitamin B complex, phosphorus and iron ${ }^{[1]}$ as well as the source of adequate soluble carbohydrates and fibres ${ }^{[2]}$. Health-promoting effects of oat improved its usefulness as dual-purpose crop ${ }^{[3]}$. But, the bulk of oat produced in the world is for fodder purpose and only $17 \%$ is used as human food. In addition, the qualitative human nutrition existed on animal products, where the quality of these products will be according to the diet provided to animals through fodder. To provide balanced nutrition to animals, it is necessary to include green fodder crops in cropping system ${ }^{[4]}$ and the availability of quality fodder throughout the year is important for cost-effective livestock production.

In India, the productivity of oat is about 35-40 tonnes hectare ${ }^{-1}$ as green fodder ${ }^{[5]}$ which is extremely poor in contrast to world productivity. The exploitation of quality seed at initial cultivation schedule is fundamental to achieve the system upgradation. In present scenario, the accessibility of quality seed is very low which cannot proceed to healthy seedling establishment. Hence, the seed quality enhancement may be one of the significant factors in cultivation practice for any crop. Unfavourable environmental conditions are the major cause of poor seedling establishment and low crop yield. One way of achieving excellent crop stand is seed priming technique in which germination process initiate but radicle emergence does not arise before sowing. In ultimate, the crop plants achieve superior growth through development of uniform healthy seedling and earlier germination.

The practical method for obtaining better seedling or plant is seed priming including hydropriming, osmo-priming, halo-priming and others. Priming offers a means to advance seed 
seeds in many crops. Heydecker ${ }^{[6]}$ defined seed priming as pre-sowing treatment in osmotic solution, which allows seeds to imbibe water for proceeding the first stage of germination but prevents radicle protrusion through the seed coat. It is a well-accepted fact that priming improves germination, plant stand in addition to reduce seedling emergence time ${ }^{[7]}$. Onfarm seed priming (hydro-priming) can significantly be helpful in obtaining good crop establishment in tropical region such as sorghum, rice, maize and pigeon pea. In recent studies, halo-priming could be an effective pre-germination strategy for the successful cultivation of Jatropha in cold, arid regions ${ }^{[8]}$. The seed priming balance perpetually the prolonged storage and storage conditions ${ }^{[9]}$ in rice and a tremendous vigour enhancement in onion crop.

Very few studies were conducted on oat seed priming and were confined to studying its effect on germination percentage ${ }^{[10]}$. In the present study, the selection of suitable organic acids to build up the quality seed and recognition of proper appliance methodology for effective fodder seed production was the prime motto that compromises both the quantitative and qualitative up-gradation of Oat seed.

\section{Materials and methods}

The present field analysis was conducted at Jaguli Instructional Farm, Mohanpur, Bidhan Chandra Krishi Viswavidyalaya, Nadia, West Bengal during rabi season of 2017-18. The experiment was done on the crop Oat (Avena sativa L.) cv. JHO-99-2 through application of 10 treatments (T) including control (water treatment) in addition to 3 variable durations of soaking (D) under $25-27^{\circ} \mathrm{C}$ (table 1) as per evidence of different researchers.

Table 1: Details of various treatments and soaking durations

\begin{tabular}{|c|c|c|c|c|c|}
\hline \multirow{2}{*}{ Treatment } & \multirow{2}{*}{ Priming agents } & \multirow{2}{*}{ Concentration } & \multicolumn{3}{|c|}{ Soaking durations (hrs.) } \\
\hline & & & D1 & D2 & D3 \\
\hline $\mathrm{T} 1$ & \multirow{3}{*}{ NA (Nicotinic Acid) } & $10 \mathrm{ppm}$ & \multirow{3}{*}{$1 / 2$} & \multirow{3}{*}{1} & \multirow{3}{*}{11} \\
\hline $\mathrm{T} 2$ & & 20ppm & & & \\
\hline $\mathrm{T} 3$ & & $25 \mathrm{ppm}$ & & & \\
\hline $\mathrm{T} 4$ & \multirow{3}{*}{ SA (Salicylic Acid) } & $10 \mathrm{ppm}$ & \multirow{3}{*}{1} & \multirow{3}{*}{2} & \multirow{3}{*}{3} \\
\hline T5 & & $20 \mathrm{ppm}$ & & & \\
\hline T6 & & $25 \mathrm{ppm}$ & & & \\
\hline $\mathrm{T} 7$ & \multirow{3}{*}{ NAA (Naphthalene Acetic Acid) } & $50 \mathrm{ppm}$ & \multirow{3}{*}{6} & \multirow{3}{*}{7} & \multirow{3}{*}{8} \\
\hline $\mathrm{T} 8$ & & $75 \mathrm{ppm}$ & & & \\
\hline T9 & & $100 \mathrm{ppm}$ & & & \\
\hline T0 & control & & 8 & 8 & 8 \\
\hline
\end{tabular}

The de-husked oat seeds were soaked in aqueous solution of the above treatments with respective duration at $25-27^{\circ} \mathrm{C}$, then air-drying to restore the previous seed condition. After 3 days, the treated (primed) seeds were sown in field considering 3 replications to assess the parameters like effective tillers plant ${ }^{-}$ ${ }^{1}$, days to $50 \%$ flowering, seeds spikelet ${ }^{-1}$, spikelet panicle ${ }^{-1}$, 1000 seed weight, seed volume and seed yield plant ${ }^{-1}$.

The result was obtained through 'Two factor' analyses at 5\% level of significance and correlation study was done by OPSTAT software.

\section{Results and discussion}

The consequence of seed priming linked to quality enhancement, the field trial was more real to expose the qualitative and quantitative traits of plants. In table 2, the T8 treatment (NAA, 75ppm) was most operative considering these yield attributing characters in addition to seed yield though, a variation was also highlighted for some parameters. The superiority of T9 (NAA, 100ppm) was also high up in most characters however it was not displayed its peak value for any individual character. T4 (SA, 10ppm) may be better by producing its topmost value only for effective tillers plant ${ }^{-}$ ${ }^{1}$, spikelet panicle ${ }^{-1}, 1000$ seed weight etc. The treatment T9 confirmed superior effect in seeds spikelet ${ }^{-1}$ although the superiority was not continued for other parameters. Moreover, the parameter seeds spikelet ${ }^{-1}$ indicated non-significant demarcation among dissimilar treatments. The promising effect was also observed in treatment $\mathrm{T} 8$ indicating the topmost effect in seed volume in addition to $2^{\text {nd }}$ highest for most of the characters in significant and non-significant demarcation with the top that intensified the seed yield in ultimate.

Table 2: Seed priming influence on different field parameters

\begin{tabular}{|c|c|c|c|c|c|c|c|}
\hline \multirow[b]{2}{*}{ Treatments } & \multicolumn{7}{|c|}{ Characters } \\
\hline & Effective tillers Plant $^{-1}$ & Days to $50 \%$ flowering & spikelet panicle $^{-1}$ & seeds spikelet ${ }^{-1}$ & 1000 seed weight $(g)$ & $\begin{array}{c}\text { Seed volume } \\
(\mathrm{ml})\end{array}$ & Seed yield Plant ${ }^{-1}$ \\
\hline $\mathrm{T} 1$ & 11.73 & 87.00 & 26.25 & 2.60 & 38.16 & 0.029 & 8.28 \\
\hline $\mathrm{T} 2$ & 12.35 & 86.33 & 25.60 & 2.64 & 39.05 & 0.033 & 8.57 \\
\hline T3 & 12.27 & 86.00 & 24.68 & 2.90 & 39.69 & 0.039 & 8.44 \\
\hline $\mathrm{T} 4$ & 13.37 & 85.67 & 26.75 & 2.32 & 41.41 & 0.042 & 8.57 \\
\hline T5 & 12.80 & 86.00 & 24.77 & 2.88 & 38.32 & 0.030 & 8.44 \\
\hline T6 & 12.98 & 85.67 & 24.18 & 2.71 & 40.72 & 0.042 & 8.49 \\
\hline $\mathrm{T} 7$ & 13.17 & 86.33 & 24.27 & 3.19 & 38.41 & 0.033 & 8.27 \\
\hline T8 & 12.68 & 85.00 & 26.67 & 2.63 & 40.78 & 0.046 & 9.11 \\
\hline T9 & 12.23 & 85.83 & 22.78 & 3.31 & 37.80 & 0.036 & 8.21 \\
\hline $\mathrm{T} 10$ & 11.16 & 86.83 & 24.14 & 2.83 & 38.13 & 0.031 & 8.13 \\
\hline \multicolumn{8}{|l|}{ Mean } \\
\hline $\operatorname{Sem}( \pm)$ & 0.350 & 0.347 & 0.849 & 0.196 & 0.774 & 0.003 & 0.172 \\
\hline LSD 0.05 & 1.017 & 1.008 & 2.469 & NS & 2.250 & 0.009 & 0.500 \\
\hline
\end{tabular}


In soaking durations of seed (table 3), D2 was prominent for some characters particularly in spikelet panicle ${ }^{-1}$, seed volume, etc. Considering the different durations of treatment, the maximum characters displayed non-significant demarcation due to its minimum effectiveness for enhancing the considerable parameters of seed. Similarly, the interaction of treatment-duration showed non-significant demarcation for responsible parameters related to yield. The interaction of T8D2 showed peak functioning value though T5 (SA, 20ppm) in combination with D3 confirmed its prominence for some characters. In result, the earlier flowering may be specified as modifier of yield attributing characters and seed yield.

Table 2: Effect of treatment duration on field parameters and the interaction effects

\begin{tabular}{|c|c|c|c|c|c|c|c|}
\hline \multirow[b]{2}{*}{ Durations } & \multicolumn{7}{|c|}{ Characters } \\
\hline & $\underset{-1}{\text { Effective tillers plant }}$ & $\begin{array}{c}\text { Days to flower } \\
(50 \%)\end{array}$ & $\begin{array}{l}\text { Spikelet } \\
\text { panicle }^{-1}\end{array}$ & Seeds spikelet & $\begin{array}{c}1000 \text { seed weight } \\
\text { (g) }\end{array}$ & $\begin{array}{l}\text { Seed volume } \\
(\mathrm{ml})\end{array}$ & $\underset{-1}{\text { Seed yield plant }}$ \\
\hline D1 & 12.40 & 86.25 & 24.02 & 2.97 & 39.20 & 0.033 & 8.44 \\
\hline D2 & 12.31 & 86.15 & 25.83 & 2.67 & 38.98 & 0.039 & 8.52 \\
\hline D3 & 12.71 & 85.80 & 25.17 & 2.77 & 39.59 & 0.037 & 8.39 \\
\hline \multicolumn{8}{|l|}{ Mean } \\
\hline $\operatorname{SEm}( \pm)$ & 0.192 & 0.190 & 0.465 & 0.108 & 0.424 & 0.002 & 0.094 \\
\hline LSD 0.05 & NS & NS & 1.352 & NS & NS & 0.005 & NS \\
\hline \multicolumn{8}{|c|}{ Interaction of treatments and durations (T X D) } \\
\hline $\operatorname{SEm}( \pm)$ & 0.606 & 0.601 & 1.471 & 0.340 & 1.340 & 0.005 & 0.298 \\
\hline LSD 0.05 & 1.762 & 1.746 & NS & NS & 3.896 & NS & NS \\
\hline
\end{tabular}

In current observations, the application of different seed treatments as priming may be acted as enhancer through creation of healthy seedling followed by optimum plant growth, augmenting photosynthesis rate with optimum transpiration that may alleviate the adverse effect of water stress and also control lodging by appropriate development of plant ${ }^{[11]}{ }^{[12]}$. Seed priming with SA improved the activity of anti-oxidative isozymes like catalase, superoxide dismutase and ascorbate peroxidase etc. ${ }^{[13]}$ The reformed action of the above characters may showed its consequence in aggregate seed number and seed yield as quantitative mode ${ }^{[14]}$ with 1000 seed weight, seed volume etc. as qualitative means.

In correlation study (table 4) on considerable yield parameters, the seed yield indicated significant strong positive relationship with other parameters except days to flower and seeds spikelet ${ }^{-1}$ that may be encouraging in seed production similar to the observation on Rice ${ }^{[15]}$. The above stated two attributes exposed negatively or non-significant demarcation with other parameters though, the rest parameters exposed positive significant association with each other. The timely or earlier flowering may initiate or supportive to retain the ideal reproductive spell with acquiring situation associated to seed growth. Moreover, the reduction in seed number may also be constructive to develop quality seed through sharing its expanding seed weight and volume that may be compensated in seed yield.

Table 3: Correlation Matrix of different field parameters

\begin{tabular}{|c|c|c|c|c|c|c|}
\hline & \begin{tabular}{|c|} 
Effective \\
tillers plant $^{-1}$
\end{tabular} & Days to $50 \%$ flowering & Spikelets panicle ${ }^{-1}$ & Seeds spikelet ${ }^{-1}$ & 1000 seed weight $(g)$ & Seed volume $(\mathrm{ml})$ \\
\hline Days to flower (50\%) & \begin{tabular}{|c|}
$-0.688^{* * *}$ \\
\end{tabular} & & & & & \\
\hline Spikelets Panicle $^{-1}$ & $-0.071^{\mathrm{NS}}$ & $-0.014^{\mathrm{NS}}$ & & & & \\
\hline Seeds Spikelet ${ }^{-1}$ & $0.088^{\mathrm{NS}}$ & $-0.121^{\mathrm{NS}}$ & $-0.701^{* *}$ & & & \\
\hline 1000 seed weight $(\mathrm{g})$ & $0.403^{* *}$ & $-0.301^{* *}$ & $0.207^{\mathrm{NS}}$ & $-0.392^{* *}$ & & \\
\hline Seed volume $(\mathrm{ml})$ & $0.043^{\mathrm{NS}}$ & $-0.108^{\mathrm{NS}}$ & $0.186^{\mathrm{NS}}$ & $-0.193^{\mathrm{NS}}$ & $0.458^{* *}$ & \\
\hline Seed yield Plant ${ }^{-1}$ & $0.306^{* *}$ & $-0.363^{* *}$ & $0.304^{* *}$ & $-0.278^{* *}$ & $0.714^{* *}$ & $0.480^{* *}$ \\
\hline
\end{tabular}

In increasing different crops productivity through yield attributing parameters, the specific role of NAA was established $[16,17,18]$. But, it was also specified the advantage of salicylic acid in modification of yield attributes under seed production system ${ }^{[19]}$. Sanna et al. ${ }^{[12]}$ and Fagadar et al. ${ }^{[20]}$ suggested the variable combinations of growth regulators for enhancing chlorophyll content, soluble protein as well as other parameters which may be linked as quality and quantity enhancer of crop/seed. The diverse defending enzymes viz. peroxidase, catalase may be accelerated to create antioxidative mechanism liable for fortification of germination behaviour, seedling quality and seed vigour at field emergence.

In figure 1 , the effect of treatment application was clearly enlightened for scheduled parameters through their percent of enhancement over the control (T10). The days to 50\% flower demonstrated truly reverse relationship with the seed yield that was also followed in seeds/spikelet for most of the cases. The most promising effect was observed in seed volume which showed its real influence in seed yield contributing the most impressive seed parameter in seed production programme. 


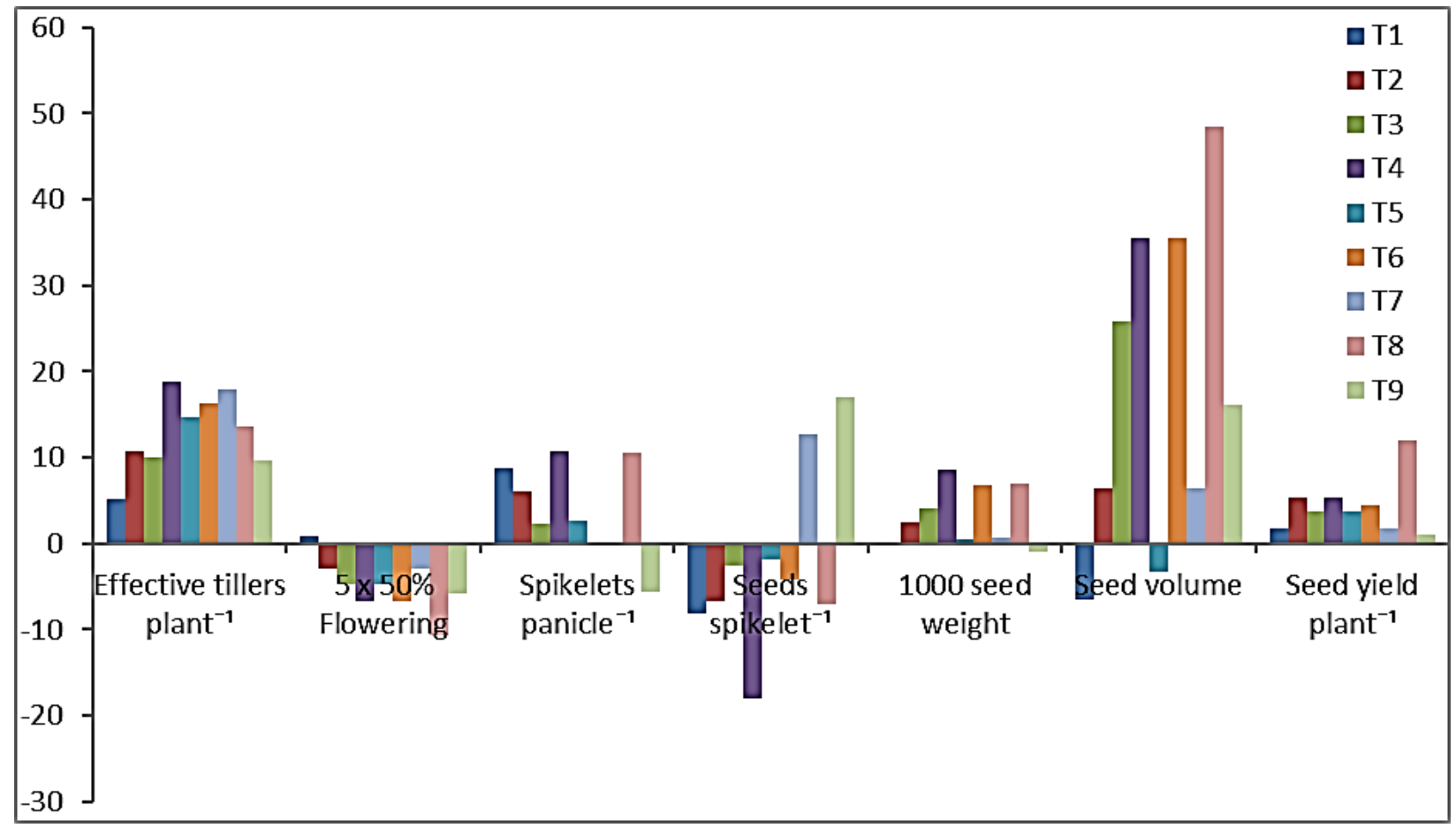

Fig 1: Enhancement of diverse parameters (in \%) over control in application of priming

T1- NA @10ppm; T2- NA @20ppm; T3- NA @ 25ppm; T4SA @10ppm; T5-SA @ 10ppm;

T6- SA @10ppm; T7- NAA @50ppm; T8- NAA @75ppm; T9- NAA@100ppm

In treatment applications, the preceding opinions were primarily limited to foliar application however seed treatments were also perceived by limited researchers on few crops. The existing experiment was restricted to seed treatment due to least association of budget in fodder seed production with consideration of its eco-friendly nature. The present observation indicated no promising effect in soaking duration while D2 i.e. medium duration for each chemical was encouraging. The superiority of T8 (NAA, 75ppm) priming treatment indicated a valuable evidence for qualitative with quantitative up-gradation of fodder seed production predominantly in Oat crop however other considerable treatments, predominantly T4 (SA, 10ppm), were also effective over control in most cases. Therefore, the selective seed treatment can be included in seed production technique to achieve quality seed of fodder.

\section{References}

1. Mehra KL. Technical Bulletin. ICAR, New Delhi, 1978.

2. Peterson DM, Wesenberg DM, Burrup DE, Erickson CA. Relationships among agronomic traits and grain composition in oat genotypes grown in different environments. Crop Science. 2005; 45(4):1249-1255.

3. Suttie JM, Reynolds SG. Fodder oats: A World Review. Plant Production and Protection Series No. 33. FAO (Rome), 2004.

4. Anonymous. Handbook of Animal Husbandry. Indian Council of Agricultural Research, New Delhi, 2002.

5. Anonymous. Forage crops and grasses, Handbook of Agriculture. ICAR, 2014.

6. Heydecker W, Higgins J, Gulliver RL. Accelerated germination by osmotic seed treatment. Nature. 1973; 246(5427):42.

7. Ahmad I, Khaliq T, Ahmad A, Shahzad MA, Basra Hasnain Z, Ali A. Exogenous Application of Ascorbic acid, Salicylic acid and Hydrogen peroxide Improves the
Productivity of Hybrid Maize at Low Temperature Stress. African Journal of Biotechnology. 2012; 11(5):11271132.

8. Yadav PV, Kumari M, Meher LC, Arif M, Ahmed Z. Chemical Seed Priming as an Efficient Approach for Developing Cold Tolerance in Jatropha. Journal of Crop Improvement. 2011; 25(5).

9. Saddam H, Zheng M, Khan F, Khaliq A, Fahad S, Peng S et al. Benefits of rice seed priming are offset permanently by prolonged storage and the storage conditions. Scientific reports, 2015.

DOI: $10.1038 /$ srep08101.

10. Shafi M, Tariq H, Akbar J, Bakht B, Rehman M. Response of wheat varieties to different levels of salinity at early growth stage. Sarhad. J. Agri. 2006; 22:585-589.

11. Harms CL, Beuerlein JE, Oplinger ES. Effect of intensive and current recommended management systems on soft winter wheat in the U.S. Corn Belt. Journal of Production Agriculture. 1989; 2(4):325-332.

12. Sanna AMZ, Mostafa MA, Shehata SAM. Physiological studies on the effect of kinetin and salicylic acid on growth and yield of wheat plant. Annals of Agricultural Science - Cairo. 2006; 51(1):41-55.

13. Shahardeen RNM, Seran TH. Impact of animal manure EM-bokashi on seed yield and quality of vegetable cowpea (Vigna unguiculata L.). Bangladesh J. Scientific and Industrial Research. 2013; 48(1):33-38.

14. Farooq M, Aziz T, Basra SMA, Cheema MA, Rehman H. Chilling Tolerance in Hybrid Maize Induced by Seed Priming with Salicylic Acid. J. Agronomy \& Crop Science. 2008; ISSN:0931-2250.

15. Mandal S, Biswas U, Chakraborti P. Genetic Variability in Seed Traits Considering Some Genotypes of Wheat. Current Journal of Applied Science and Technology. 2019; 38(6):1-8.

16. Soyler D, Khawar KM. Seed Germination of Caper (Capparisovatavar. Herbacea) using a Naphthalene Acetic Acid and Gibberellic Acid. International Journal of Agriculture and Biology. 2014; 09(1):35-37. 
17. Moniruzzaman M, Khatoon R, Hossain MFB, Jamil MK, Islam MN. Effect of GA3 and NAA on physiomorphological characters, yield and yield components of brinjal (Solanum melongena L.). Bangladesh J. Agril. Res. 2014; 39(3):397-405.

18. Luckwill LC. Studies of plant harmones in relation to plant harmones: II. The effect of NAA on fruit set and fruit development in Apples. Journal of Horticulture Sciences. 2015; 28(1).

19. Hosseinzadeh M, Shekari F, Janmohammadi M, Sabaghnia N. Effect of sowing date and foliar application of salicylic acid on forage yields and quality of globe artichoke (Cynara scolymusL.). 2013; LXVIII(2).

20. Fagadar - Cosma, E, Fagadar - Cosma, G, Laichici, M, Vlascici, D. Chlorophylls a and b content development in wheat treated with a phosphonium compound. Agrochimica. 2005; 49(1-2):51-59. 